American Journal of Agricultural and Biological Sciences 3 (3): 591-596, 2008

ISSN 1557-4989

(C) 2008 Science Publications

\title{
A Thermostable $\alpha$-Amylase Producing Natural Variant of Bacillus spp. Isolated From Soil in Iran
}

\author{
Iraj Rasooli, Shakiba Darvish Alipoor Astaneh, Hojjat Borna and Kamal Azizi Barchini \\ Department of Biology, Shahed University, Opposite Imam Khomeini’s Shrine, \\ Tehran-Qom High way, Tehran, Iran
}

\begin{abstract}
Thermophilic processes appear more stable, rapid and less expensive and facilitate reactant activity and product recovery. Amylases have a quarter of the world enzyme market and thermostable $\alpha$-amylases possess extensive commercial applications. Since little work has been done on strain isolation, growth and enzyme yield optimization, the level of thermophilic enzyme production remains relatively low. Therefore, large scale exploitation of thermophiles requires further intensive and integrated work. The present study describes isolation of an $\alpha$-amylase producing bacillus from soil. The isolated bacillus was identified and named as Bacillus licheniformis Shahed-07. The strain was cultured in liquid media to produce $\alpha$-amylase. The enzyme production conditions of the newly isolated bacillus revealed that the maximum enzyme production after $26 \mathrm{~h}$ of cultivation at $\mathrm{pH} 7.0$ and $50^{\circ} \mathrm{C}$. $0.5 \%$ tryptophan in production medium enhanced the enzyme productivity to two fold whereas peptone and lysin at $0.5 \%$ level showed a strong repression. Crude $\alpha$-amylase characterization revealed that optimum activity was at $\mathrm{pH} 7.5$ and $70^{\circ} \mathrm{C}$. The crude enzyme was stable for $24 \mathrm{~h}$ at $\mathrm{pH}$ range of 6-7 at $70^{\circ} \mathrm{C}$. Enzyme activity increased with temperature within the range of $40-70^{\circ} \mathrm{C}$. The Bacillus licheniformis Shahed-07 strain produced thermostable $\alpha$-amylase with characteristics suitable for application in starch processing and food industries.
\end{abstract}

Key words: Thermostable $\alpha$-amylase, Bacillus licheniformis shahed-07, media optimization, characterization, starch processing

\section{INTRODUCTION}

Starch, a main component of our daily diet, is frequently found not only in food residues on dishes but also in food stains on clothes. Amylases are among the most important enzymes and are of great significance in present-day biotechnology. Amylases having approximately $25 \%$ of the enzyme market have almost completely replaced chemical hydrolysis of starch in starch processing industry ${ }^{[1]}$. Thermostable $\alpha$-amylases have had extensive commercial applications in starch processing, brewing and sugar production ${ }^{[2]}$. Thermophilic processes appear more stable, rapid and less expensive and facilitate reactant activity and product recovery. Bacteria belonging to the genus Bacillus have been widely used for the commercial production of thermostable $\alpha$-amylases. The most important characteristic of thermophilic organisms is their ability to produce thermostable enzymes with a higher operational stability and a longer shelf-life ${ }^{[3]}$. It is desirable that $\alpha$-amylases should be active at the high temperatures of gelatinization $\left(100-110^{\circ} \mathrm{C}\right)$ and liquefaction $\left(80-90^{\circ} \mathrm{C}\right)$ to economize processes; therefore, there has been a need and continual search for more thermopile and thermostable $\alpha$-amylases ${ }^{[4]}$. Thermophilic bacteria are common in soil and volcanic habitats and have a limited species composition. Yet they possess all the major nutritional categories and metabolize the same substrates as mesophilic bacteria. The ability to proliferate at growth temperature optima well above $60^{\circ} \mathrm{C}$ is associated with extremely thermally stable macromolecules. As a consequence of growth at high temperature and unique macromolecular properties, thermophilic bacteria can possess high metabolic rates, physically and chemically stable enzymes and lower growth but higher end product yields than similar mesophilic species. Thermophilic processes appear more stable, rapid and less expensive and facilitate reactant activity and product recovery. Bacteria belonging to the genus Bacillus have been widely used for the commercial production of thermostable $\alpha$-amylases. The most important

Corresponding Author: Iraj Rasooli, Department of Biology, Shahed University, Opposite Imam Khomeini's Shrine, Tehran-Qom Highway, Tehran, Iran Tel: +98(21)55277647 Fax: +98(21)55277639 
characteristic of thermophilic organisms is their ability to produce thermostable enzymes with a higher operational stability and a longer shelf-life ${ }^{[3]}$. Bacillus licheniformis $\alpha$-amylase (BLA) is among the most extensively thermostable natural enzymes used in starch technology and in the biotechnological processes. Although it is encoded by a nonthermophilic bacteria, it remains active for several $h$ at temperatures over $90^{\circ} \mathrm{C}$ under conditions of industrial starch hydrolysis ${ }^{[5]}$. Very few studies have been performed on strain selection, growth and enzyme yield optimization and the level of thermophilic enzyme production remains relatively low. Since little work has been done on strain selection, growth and enzyme yield optimization, the level of thermophilic enzyme production remains relatively low ${ }^{[6]}$. Therefore, large scale exploitation of thermophiles requires further intensive and integrated work. In this study we have made an attempt to isolate and identify a thermostable amylase producing Bacillus. The enzyme production conditions of the newly isolated Bacillus are also reported here.

\section{MATERIALS AND METHODS}

Selection, isolation and identification of bacterial strain: Bacillus licheniformis Shahed-07, a moderate thermophilic bacterium was isolated in the Department of Microbiology, Shahed University, Tehran, Iran during the year 2007. Two samples from positive growth on nutrient agar medium I consisting of $2 \%$ peptone, $1 \%$ yeast extract, $1 \% \mathrm{NaCl}$ and $2 \%$ agar at $\mathrm{pH} 7.0$ were selected after $48 \mathrm{~h}$ of incubation at $55^{\circ} \mathrm{C}$. The bacterial colonies appearing on plate I were transferred to medium II containing $1 \%$ soluble starch, $0.2 \%$ yeast extract, $0.5 \%$ peptone, $0.1 \% \mathrm{MgSO}_{4}$, $0.1 \% \mathrm{NaCl}, 0.02 \% \mathrm{CaCl}_{2}$ and $2 \%$ agar at $\mathrm{pH}$ 7.0. These cultures were incubated at $55^{\circ} \mathrm{C}$ for $48 \mathrm{~h}$. Typical cultural and morphological characteristics were observed for Bacillus species. Amylase producing colonies were selected by flooding the media II plates with iodine solution. The isolated Bacillus was identified by morphological and biochemical examination.

Enzyme production medium: The enzyme production was carried out at $55^{\circ} \mathrm{C}$ (except temperature optimization experiment) in a rotary shaker at $150 \mathrm{rpm}$ for $144 \mathrm{~h}$ in $100 \mathrm{~mL}$ of the basal medium of the following composition: Soluble Starch (1\%), Maltose (1\%), $\left(\mathrm{NH}_{4}\right)_{2} \mathrm{SO}_{4}(0.2 \%), \mathrm{CaCl}_{2} \quad\left(10^{-4} \mathrm{M}\right), \mathrm{K}_{2} \mathrm{HPO}_{4}$ $\left(10^{-1} \mathrm{M}\right), \mathrm{MgCl}_{2}, 6 \mathrm{H}_{2} \mathrm{O}(0.02 \%), \mathrm{pH}$ 7. At regular intervals $(2 \mathrm{~h})$, the triplicate samples were harvested and the cells were separated by centrifugation $(10,000 \times \mathrm{g} 20 \mathrm{~min})$ at $4^{\circ} \mathrm{C}$ in a refrigerated centrifuge. The supernatant was used for enzyme assay and characterization studies.

$\boldsymbol{\alpha}$-amylase assay: The activity of $\alpha$-amylase was assayed by incubating $0.5 \mathrm{~mL}$ enzyme with $0.5 \mathrm{~mL}$ soluble starch $(1 \%$, w/v) prepared in $0.1 \mathrm{M}$ sodium phosphate buffer ( $\mathrm{pH} 7.0)$. After incubation at $70^{\circ} \mathrm{C}$ for $60 \mathrm{~min}$ the reaction was stopped by the addition of 2 ML of 3-5-dinitrosalicylic acid reagent ${ }^{[7]}$ and absorbance was measured in a UV/vis spectrophotometer (Biofuge). One unit (U) is defined as the amount of enzyme which releases $1 \mu \mathrm{mol}$ of reducing end groups $\mathrm{min}^{-1}$ in $0.1 \mathrm{M}$ sodium phosphate buffer $(\mathrm{pH} 7.0)$ with $0.5 \%(\mathrm{w} / \mathrm{v})$ soluble starch as substrate at $55^{\circ} \mathrm{C}$.

Optimization of medium and culture conditions: The basal medium containing $1 \%$ (w/v) soluble starch was supplemented with organic and inorganic nitrogen sources, each at a concentration of $0.5 \%(\mathrm{w} / \mathrm{v})$. Nitrogen sources were tryptone, proteose peptone and yeast extract. The effect of varying $\mathrm{pH}$ values $(5-10)$ and temperatures $\left(30-100^{\circ} \mathrm{C}\right)$ on $\alpha$-amylase production by the bacterium was also investigated. In all cases, $100 \mathrm{~mL}$ medium in $500 \mathrm{~mL}$ baffled flasks was inoculated with $2 \%(\mathrm{v} / \mathrm{v})$ of an overnight culture. The culture was incubated under shaking in an incubator shaker at a shake rate of $150 \mathrm{rpm}$ and under stationary conditions. Growth was determined spectrophotometrically by measuring optical density of the culture at $600 \mathrm{~nm}$. The cell dry weight was determined by centrifugating $10 \mathrm{~mL}$ culture suspension taken at each time intervals at $10000 \mathrm{~g}$ and drying the cell mass overnight at $45^{\circ} \mathrm{C}$.

Effect of pH on enzyme activity and stability: The $\mathrm{pH}$ optimum of the enzyme was determined by varying the $\mathrm{pH}$ of the assay reaction mixture using the following buffers $(0.1 \mathrm{M})$ : sodium acetate $(\mathrm{pH}$ 5.0-5.5), sodium phosphate $(\mathrm{pH}$ 6.0-7.0), Tris- $\mathrm{HCl}(\mathrm{pH} 7.5-8)$ and glycine- $\mathrm{NaOH}$ buffer ( $\mathrm{pH} 9-10)$. To determine the stability of $\alpha$-amylase, the enzyme was pre-incubated in different buffers ( $\mathrm{pH} \mathrm{5-10)}$ for $24 \mathrm{~h}$. The residual enzyme activity was determined.

Effect of temperature on enzyme activity and stability: The temperature optimum of the enzyme was evaluated by measuring the $\alpha$-amylase activity at different temperatures $\left(30-100^{\circ} \mathrm{C}\right)$ in $0.1 \mathrm{M}$ sodium 
phosphate buffer ( $\mathrm{pH}$ 7.5). The effect of temperature on amylase stability was determined by measuring the residual activity after $24 \mathrm{~h}$ of pre-incubation in $0.1 \mathrm{M}$ sodium phosphate buffer $(\mathrm{pH}$ 7.5), at temperatures ranging from $30-100^{\circ} \mathrm{C}$.

\section{RESULTS AND DISCUSSION}

The isolated Bacillus strain was characterized by various parameters and it was confirmed to be Bacillus licheniformis (Table 1). The Bacillus strain was named as Bacillus licheniformis Shahed-07. The results on the time-course studies on $\alpha$-amylase production and cell growth of Bacillus licheniformis Shahed-07 grown in basal medium supplemented with $1 \%$ soluble starch as inducer substrate in both shake flasks and stationary condition are shown in Fig. 1 and 2 respectively. It was observed that maximum $\alpha$-amylase production by $B$. licheniformis Shahed-07 occurred when cell population reached the peak in shake flasks (Fig. 1). In the stationary cultures the peak enzyme activity was noted at the stationary phase of growth (Fig. 2). The $\mathrm{pH}$ and the optimum temperature for growth and enzyme production were 7.0 and $50^{\circ} \mathrm{C}$ respectively (Fig. 3, 4). There was a stimulation of enzyme synthesis with an increase in $\mathrm{pH}$ from 5-7 and higher enzyme synthesis at $\mathrm{pH} 7.0$ is a result of enhanced bacterial growth. The $\mathrm{pH}$ change observed during the growth of the organism also affects product stability in the medium. Enzyme synthesis occurred at temperatures between 30 and $80^{\circ} \mathrm{C}$. The bacterium could grow satisfactorily at all temperatures tested but the maximal $\alpha$-amylase activity in the growth medium was achieved at $50^{\circ} \mathrm{C}$ (Fig. 4). A reduction in enzyme activity was observed at temperatures above $55^{\circ} \mathrm{C}$. $\alpha$-amylase production peaked at $26 \mathrm{~h}$ and was found to decline gradually after $30 \mathrm{~h}$. The influence of various carbon and nitrogen sources on $\alpha$-amylase production was quantified in batch fermentation in shake flasks. Starch at $2 \%$ level had positive impact on the enzyme productivity. Among defined carbohydrates, tested starch and maltose supported good growth and amylase production, with the highest productivity recorded in the presence of starch. The productivity remained constant up to $8 \%$ starch level after which it gradually declined (Fig. 5). Tryptophan was found to enhance the enzyme productivity to $202 \%$ as compared to the basal medium whereas peptone and lysin at $0.5 \%$ level showed a strong repression (Fig. 6).

Most of the Bacillus strains used commercially for the production of $\alpha$-amylases have an optimum $\mathrm{pH}$ between 6.0 and 9.0 for growth and enzyme production $^{[4]}$. Neutral $\mathrm{pH}$ was found to be optimal for
Table 1: Characterization of B. licheniformis Shahed-07 and comparison with the characteristics of standard B. licheniformis

\begin{tabular}{|c|c|c|}
\hline Tartrate characteristics & B. licheniformis & $\begin{array}{l}\text { B. licheniformis } \\
\text { Shahed-07 }\end{array}$ \\
\hline Spores round & - & - \\
\hline Parasporal crystals & - & - \\
\hline Catalase & + & + \\
\hline Anaerobic growth & + & + \\
\hline Voges-Proskauer test & + & + \\
\hline \multicolumn{3}{|l|}{$<6$} \\
\hline$>7$ & - & + \\
\hline \multicolumn{3}{|l|}{ Acid from } \\
\hline D-Glucose & + & + \\
\hline L-Arabinose & + & + \\
\hline D-Mannitol & + & + \\
\hline Gas from glucose & $(-)^{P}$ & - \\
\hline \multicolumn{3}{|l|}{ Hydrolysis of } \\
\hline Casein & + & + \\
\hline Gelatin & + & + \\
\hline Starch & + & + \\
\hline Utilization of citrate & + & - \\
\hline Degradation of tyrosine & - & + \\
\hline Deamination of phenylalanine & - & - \\
\hline Egg-yolk lecithinase & - & - \\
\hline Nitrate reduced to nitrite & + & + \\
\hline \multicolumn{3}{|l|}{ Formation of } \\
\hline Indole & - & - \\
\hline Dihydroxyactone & ND & - \\
\hline $\mathrm{NaCl}$ and $\mathrm{KCl}$ required & - & - \\
\hline \multicolumn{3}{|l|}{ Growth at $\mathrm{pH}$} \\
\hline 6.8 nutrient broth & + & + \\
\hline 5.7 & + & + \\
\hline \multicolumn{3}{|l|}{ Growth at $\mathrm{NaCl}$} \\
\hline $2 \%$ & + & + \\
\hline $5 \%$ & + & + \\
\hline $7 \%$ & + & + \\
\hline $10 \%$ & ND & - \\
\hline \multicolumn{3}{|l|}{ Growth at } \\
\hline $5^{\circ} \mathrm{C}$ & - & - \\
\hline $10^{\circ} \mathrm{C}$ & + & - \\
\hline $30^{\circ} \mathrm{C}$ & + & + \\
\hline $40^{\circ} \mathrm{C}$ & + & + \\
\hline $50^{\circ} \mathrm{C}$ & + & + \\
\hline $55^{\circ} \mathrm{C}$ & + & + \\
\hline $65^{\circ} \mathrm{C}$ & + & - \\
\hline Oxidase & $\mathrm{d}$ & + \\
\hline Argenine dihydrolase & + & + \\
\hline Lysine decarboxylase & - & + \\
\hline Lipase (olive oil) & $\mathrm{d}$ & + \\
\hline \multicolumn{3}{|l|}{ Hydrolysis of } \\
\hline Tween 80 & & + \\
\hline Urea & - & + \\
\hline Gas from nitrate & $\mathrm{d}$ & - \\
\hline Growth at $\mathrm{pH} 5$ & & + \\
\hline Growth factors required & - & - \\
\hline \multicolumn{3}{|l|}{ Reduction of methylene blue } \\
\hline \multicolumn{3}{|l|}{ Acid from } \\
\hline Fructose & & + \\
\hline Galactose & & + \\
\hline Glycerol & & + \\
\hline Lactose & & - \\
\hline Maltose & & + \\
\hline Sucrose & & + \\
\hline
\end{tabular}


Table 1: Continued

Formation of poly- $\beta$-hydroxy-

butyrate or other storage products

Utilization of

Acetate

Glycerol

Glycine

Mannitol

-: Ninety percent or more of strains are negative; + : Ninety percent or more of strains are positive; $(-)^{\mathrm{P}}$ : Few gas bubbles may be formed; ND: No data available; NG: No growth; D: Eleven to eighty nine percent of strains are positive

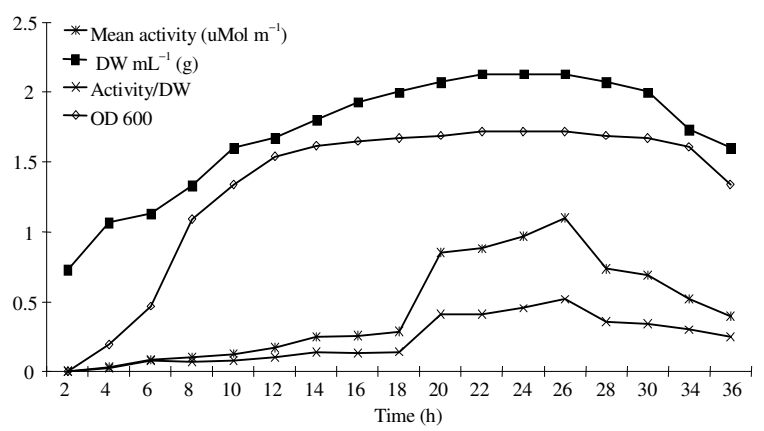

Fig. 1: Microbial growth and $\alpha$-amylase production in shake flasks

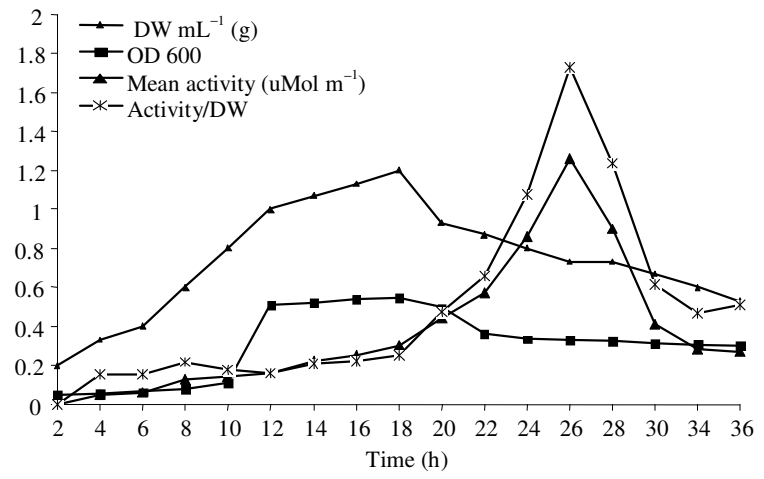

Fig. 2: Microbial growth and $\alpha$-amylase production in stationary flasks

amylase production as also reported in $B$. thermooleovorans $\mathrm{NP5} 4^{[8]}$, B. coagulans $^{[9]}$, B. licheniformis $^{[10]}$, B. subtilis JS-2004 ${ }^{6}$ and B. brevis $^{[11]}$. The strain Bacillus licheniformis Shahed07 possessed the ability to produce $\alpha$-amylase and hydrolyze starch. Among the physical parameters, the $\mathrm{pH}$ of the growth medium plays an important role by inducing morphological change in the organism and in enzyme secretion. The influence of temperature on amylase production is related to the growth of the organism. A wide range of temperature $\left(35-80^{\circ} \mathrm{C}\right)$ has been reported for optimum growth and $\alpha$-amylase

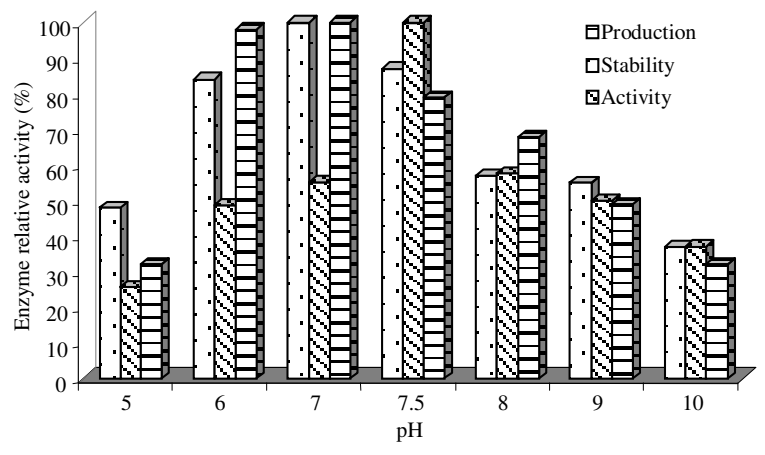

Fig. 3: Effect of $\mathrm{pH}$ on relative productivity, stability and activity of $\alpha$-amylase

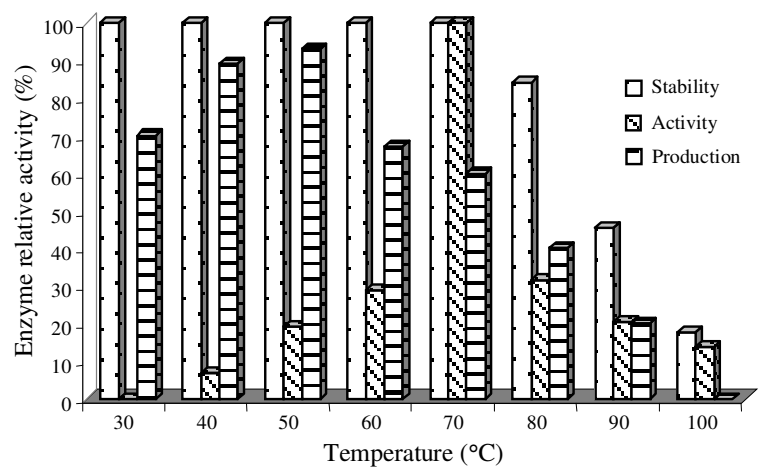

Fig. 4: Effect of temperature on relative productivity, activity and stability of $\alpha$-amylase

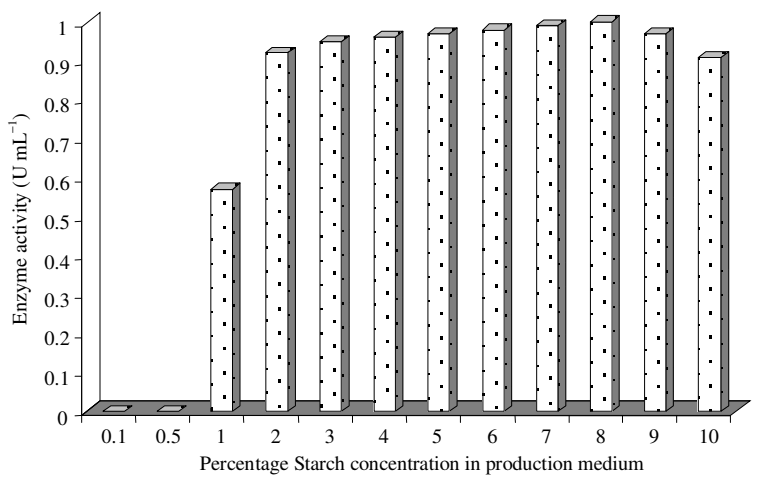

Fig. 5: Effect of substrate concentration on $\alpha$ amylase productivity of $B$. licheniformis Shahed-07

production in bacteria ${ }^{[4]}$. Konsula and LiakopoulouKyriakides $^{[12]}$ reported that a thermophilic B. subtilis strain, isolated from fresh sheep's milk, produced maximum extracellular thermostable $\alpha$-amylase at $40^{\circ} \mathrm{C}$ in a medium containing low starch concentration. 
Am. J. Agri. \& Biol. Sci., 3 (3): 591-596, 2008

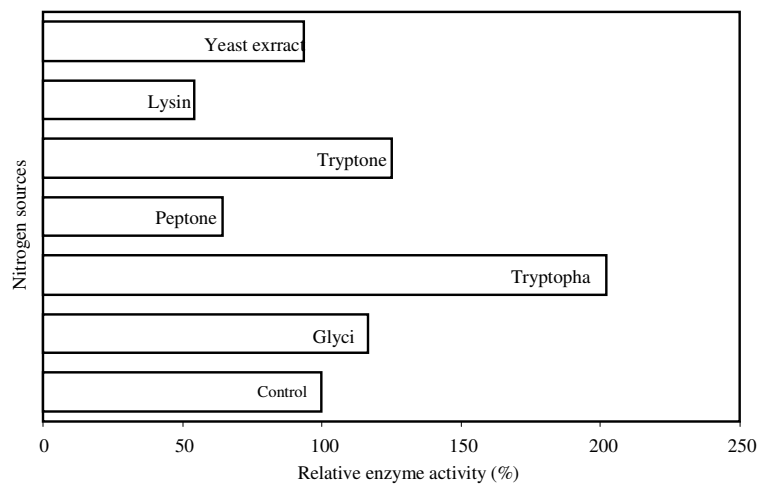

Fig. 6: Effect of various nitrogen sources on $\alpha$-amylase production

Members of the genus Bacillus produce a large variety of extracellular enzymes of which amylases are of particularly significant industrial importance. Showing similarity to $B$. thermooleovorans NP54 $4^{[8]}$, B. licheniformis Shahed-07 showed to produce $\alpha$ amylase maximally at its optimal growth temperature $\left(50^{\circ} \mathrm{C}\right)$. A thermostable extracellular amylase from a bacillus isolate had an optimum temperature and $\mathrm{pH}$ of $60^{\circ} \mathrm{C}$ and 6.5 , respectively ${ }^{[13]}$. Our strain showed higher thermal activity of $70^{\circ} \mathrm{C}$ which being an advantage is comparable to that described for other Bacillus $\alpha$ amylases $^{[4]}$. $\alpha$-amylase production from $B$. subtilis JS2004 was reported to be highest at $48 \mathrm{~h}$ declining gradually up to $96 \mathrm{~h}^{[6]}$. Effective induction may not occur until the stationary phase has been reached and the readily available carbon source was depleted ${ }^{[14]}$. Culture conditions have been found to have a profound influence on amylase production. The enzyme production was maximal when the cell population entered into stationary phase, suggesting that enzyme secretion is not growth associated. $\alpha$-amylase from Bacillus licheniformis has been produced during the growth phase and not at the onset of the stationary phase $^{[15]}$. The results of this study do not favor this report. A newly isolated B. licheniformis Shahed-07 strain was cultured in liquid media containing soluble starch to produce $\alpha$-amylase. The maximum amylase production has been reported to be achieved with maltose as carbon source. Among the nitrogen sources, peptone and yeast extract produced maximum amylase $^{[13]}$. Barley and corn flour have been reported to result in maximum amylase production compared to $\operatorname{starch}^{[16]}$. Amylase production by this strain is inducible since the enzyme synthesis took place only in presence of starch. The effect of glycine, tryptophan, peptone, tryptone, lysine and yeast extract supplementation of the production medium on enzyme production was studied. Starch and tryptone have been reported to be the ideal carbon and nitrogen sources, respectively ${ }^{[17]}$. The amylase synthesis by several microorganisms has been correlated to the presence or absence of different nitrogen sources and various amino acids in the growth medium. Organic sources like yeast extract, peptone usually have stimulating effects ${ }^{[18]}$. The differences in nutritional requirements of various $\alpha$-amylase producing organisms or microbial strains could be attributed to the difference in their genetics. Studies on crude $\alpha$-amylase characterization revealed that optimum activity was at $\mathrm{pH} 7.5$ and $70^{\circ} \mathrm{C}$ (Fig. 3 and 4). The crude enzyme was stable for $24 \mathrm{~h}$ at $\mathrm{pH}$ range of 6-7 at $70^{\circ} \mathrm{C}$ (Fig. 3). The enzyme was quite stable at $70^{\circ} \mathrm{C}$, while at 80 and $90^{\circ} \mathrm{C}, 16$ and $54 \%$ of the original activities were lost, respectively (Fig. 4). Enzyme activity increased with temperature within the range of $40-70^{\circ} \mathrm{C}$. A reduction in enzyme activity was observed at temperatures above $70^{\circ} \mathrm{C}$. Thermostability for $4 \mathrm{~h}$ at $100^{\circ} \mathrm{C}$ have been reported for $\alpha$-amylase from B. licheniformis CUMC $305^{[10]}$. Bacillus sp. ANT-6 $\alpha-$ amylase was stable after overnight $(85.5 \%)$ and $24 \mathrm{~h}$ $(55 \%)$ incubation at $100^{\circ} \mathrm{C}$ and $\mathrm{pH} 10.5^{[4]}$. A strain of Bacillus stearothermophilus isolated from the samples of a potato processing industry had a highly thermostable $\alpha$-amylase. The temperature optimum for the activity of this enzyme was $70^{\circ} \mathrm{C}$ but $\mathrm{pH}$ optimum for activity was relatively low, in the range 5.5-6. $0^{[19]}$. $\alpha$-amylases from Bacillus genus are heat stable and this is a desirable property for industrial starch liquefaction. Higher operational stability and a longer shelf-life of the enzyme produced by $B$. licheniformis Shahed- 07 could be encouraging factors to consider further studies on its industrial application.

\section{CONCLUSIONS}

The B. licheniformis Shahed-07 strain produced thermostable $\alpha$-amylase with characteristics suitable for application in starch processing and other food industries. Further optimization for enhanced enzyme production for commercialized process is needed.

\section{ACKNOWLEDGEMENT}

The authors wish to thank Shahed University (Tehran-Iran) for the sanction of research grants to conduct the present study. Special thanks to Mr. Mohammad Habibi for his laborious works in our Microbiology laboratory. 


\section{REFERENCES}

1. Pandey, A., P. Nigam, C.R. Soccol, V.T. Soccol, D. Singh and R. Mohan, 2000. Advances in microbial amylases. Biotechnol. Applied Biochem., 31: 135-152.

2. Leveque, E., S. Janecek, B. Haye and A. Belarbi, 2000. Thermophilic archaeal amylolytic enzymescatalytic mechanism, substrate specificity and stability. Enzyme Microbiol. Technol., 26: 3-14.

3. Niehaus, F., C. Bertoldo, M. Kahler and G. Antranikian, 1999. Extremophiles as a source of novel enzymes for industrial application. Applied Microbiol. Biotechnol., 51: 711-729.

4. Burhan, A., U. Nisa, C. Gokhan, C. Omer, A. Ashabil and G. Osman, 2003. Enzymatic properties of a novel thermostable, thermophilic, alkaline and chelator resistant amylase from an alkaliphilic Bacillus sp. isolate ANT-6. Process Biochem., 38: 1397-1403.

5. Lee, S., H. Oneda, M. Minoda, A. Tanaka and K. Inouye. 2006. Comparison of starch hydrolysis activity and thermal stability of two Bacillus licheniformis $\alpha$-amylases and insights into engineering $\alpha$-amylase variants active under acidic conditions. J. Biochem. (Tokyo), 139: 9971005.

6. Asgher, M., M.J. Asad, S.U. Rahman, R.L. Legge, 2007. A thermostable $\alpha$-amylase from a moderately thermophilic Bacillus subtilis strain for starch processing. J. Food Eng., 79: 950-955.

7. Bernfeld, P., 1951. Enzymes of Starch Degradation and Synthesis. In: Advances in Enzymology, Nord, F. (Ed.). Vol. XII Interscience Publ., NY, pp: 379.

8. Malhotra, R., S.M. Noorwez and T. Satyanarayana, 2000. Production and partial characterization of thermostable and calcium-independent $\alpha$-amylase of an extreme thermophile Bacillus thermooleovorans NP 54. Lett. Applied Microbiol., 31: 378-384.

9. Medda, S. and A.K. Chandra, 1980. New strains of Bacillus licheniformis and Bacillus coagulans producing thermostable $\alpha$-amylase active at alkaline pH. J. Applied Bacteriol., 48: 47-58.
10. Krishnan, T. and A. K. Chandra. 1983. Purification and Characterization of $\alpha$-amylase from Bacillus licheniformis CUMC305. Applied Environ. Microbiol., 46: 430-437.

11. Tsvetkov, V.T. and E.I. Emanuilova, 1989. Purification and properties of heat stable $\alpha-$ amylase from Bacillus brevis. Applied Microbiol. Biotechnol., 31: 246-248.

12. Konsula, Z. and M. Liakopoulou-Kyriakides, 2004. Hydrolysis of starches by the action of an $\alpha$ amylase from Bacillus subtilis. Process Biochem., 39: 1745-1749.

13. Thippeswamy, S., K. Girigowda and V.H. Mulimani, 2006. Isolation and identification of $\alpha$-amylase producing Bacillus sp. from dhal industry waste. Ind. J. Biochem. Biophys., 43: 295-298.

14. Wanderley, K.J., F.A.G. Torres, L. Moraes and C.J. Ulhoa, 2004. Biochemical characterization of $\alpha$-amylase from the yeast Cryptococcus flavus. FEMS Microbiol. Lett., 231: 165-169.

15. Rothstein, D.M., P.E. Devlin and R.L. Cate, 1986. Expression of $\alpha$-amylase in Bacillus licheniformis. J. Bacteriol., 168: 839-842

16. Mamo, G. and A. Gessesse, 1999. Effect of cultivation conditions on growth and $\alpha$-amylase production by a thermophilic Bacillus sp. Lett. Applied Microbiol., 29: 61-65.

17. Narang, S. and T. Satyanarayana, 2001. Thermostable $\alpha$-amylase production by an extreme thermophile Bacillus thermooleovorans. Lett. Applied Microbiol., 32: 31-35.

18. Hamilton, L.M., C.T. Kelly and W.M. Fogarty, 1999. Production and properties of the raw starchdigesting $\alpha$-amylase of Bacillus sp. IMD 435. Process Biochem., 35: 27-31.

19. Wind, R.D., R.M. Buitelaar, G. Eggink, H.J. Huizing and L. Dijkhuizen, 1994. Characterization of a new Bacillus stearothermophilus isolate: A highly thermostable $\mathrm{X}$-amylase producing strain. Applied Microbiol. Biotechnol., 41: 155-162. 